\title{
円柱状ぜい性材料供試体の一軸圧縮強度に 対する有限要素解析について \\ FINITE ELEMENT ANALYSIS ON UNIAXIAL COMPRESSIVE STRENGTH OF CYLINDRICAL BRITTLE SPECIMEN
}

\section{1. ま え がき}

著者らは土木学会論文報告集第 166 号において, 円柱 ぜマ性材料供試体の一軸圧縮試験における加圧面拘束が 変形状態や一軸圧縮強度におよぼす影響について, 軸対 称有限要素法を用いて行なった研究成果を発表した ${ }^{1)}$ 。 その際，材料が非線形性質を有する場合に対して非線形 解析を行ない, 種々の荷重段階における荷重一変形関係 および供試体内の各位置での応力ーひず関係, 変形係 数の変化の状態などを求め, さらに, 弾塑性解析を行な って, 供試体内の塑性領域が拡がる過程, 破壊時の全変 形量およびひずみ分布, せん断ひずみエネルギー分布な どを求め, それらの結果から, 破壊荷重 (圧縮強度) や 破壊形状について考察した。その場合, 破壊包絡線とし ては一軸引張強度 $\sigma_{t}$ で規定される Griffith-Mohr 包絡 線 $\tau^{2}=4 \sigma_{t}\left(\sigma_{t}-\sigma\right)$ を用い, 応力ーひずみ関係としては完 全弾塑性的 (bi-linear な) 関係と, 指数関数的な関係を もつ非線形的なものとを考えて，解析が進められた。

bi-linear な応力ーひずみ関係を用いた荷重漸増法によ る解析結果では, 荷重の増加による塑性域の発達過程が 明確にわかり，塑性域が試験体の断面を横切った場合を 供試体の破壊と見なして圧縮強度を算定した。一方, 非 線形な応力ーひずみ関係を用いた反復法による結果では, 種々の荷重段階における変形倸数の変化の状態などは明 らかになるが，塑性域のひろがりは直接には求められな い。したがって, 平均荷重強度と加圧面の変位との関係 から, それらの関係が急変し, 圧縮強度が加圧面の変形 量の増大に対して頭うちの状態になるときを供試体の破 壊と考えて, 強度の算定を行なった。その結果, 両者に おいて仮定された応力ーひずみ関係が異なるにもかかわ

\footnotetext{
* 学生員 工修 名古屋大学大学院工学研究科 土木工学専 攻博士課程在学

** 正会員 工博 名古屋大学助教授 工学部土木工学教室
}

梶田 建 夫*.川本朓 万** By Tateo Kajita and Toshikazu Kawamoto

らず，同一の圧縮強度が求められ，また，解析結果と実 験結果とは質的にはかなりよく一致するが，量的にはか なりの差異が認められた。すなわち，仮定された降伏条 件では, 圧縮強度の解析值は実験值よりもかなり低い。 これは前論文で考察したように，もっぱら降伏条件の不 適合に原因しているものと考えられる。

それゆえ，ここでは前論文発表以後に降伏条件を変え て解析を行なって得た結果を示し, 有限要素法によるこ の種の問題の解析の妥当性を検討するとともに，ぜい性 体の弾塑性解析において考慮すべき点を指摘した。

\section{2. 応カーひずみ関係および破壊包絡線}

さきの論文ではモルタルの純三軸圧縮試験の結果に基 ゔいて，その降伏条件が Griffith-Mohr 包絡線で近似で きるものと仮定したが，ここではモルタル，片岩および 大理石について行なった三軸試鈳結果を示し，解析に用 いる応力ーひずみ関係および降伏条件について考えた。

三軸圧縮状態で破壞試験を行なって得た結果は, 平均 応力 $\sigma_{m}$ をパラメーターとして，それぞれ次式で表わさ れる八面体せん断応力 $\tau_{\text {oct }}$ と八面体せん断ひずみ $r_{\text {oct }}$ との関係で示された。

$$
\begin{array}{r}
\tau_{\text {oct }}=(1 / 3) \sqrt{\left(\sigma_{1}-\sigma_{2}\right)^{2}+\left(\sigma_{2}-\sigma_{3}\right)^{2}+\left(\sigma_{3}-\sigma_{1}\right)^{2}} \\
\ldots \ldots \ldots \ldots \ldots \ldots \ldots \cdots \cdots \cdots \cdots \cdots \cdots \cdots \cdots \cdots \cdots \\
r_{\text {oct }}=(2 / 3) \sqrt{\left(\varepsilon_{1}-\varepsilon_{2}\right)^{2}+\left(\varepsilon_{2}-\varepsilon_{3}\right)^{2}+\left(\varepsilon_{3}-\varepsilon_{1}\right)^{2}}
\end{array}
$$

モルタル，片麻岩および大理石に対する応力ーひずみ

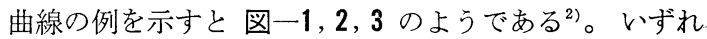
の場合にも拘束応力としての平均応力 $\sigma_{m}$ の值によって 破壊までの曲線が変化することがわかる。しかし， $\tau_{\text {oct }}$ の低いところでは $\sigma_{m}$ の大きさは応力ーひずみ関係には大 きくは影響を与えず，ほぼ一本の直線で表わされるが， $\sigma_{m}$ の大きさに応じて $\tau_{\text {oct }}$ がある值以上になると, この 


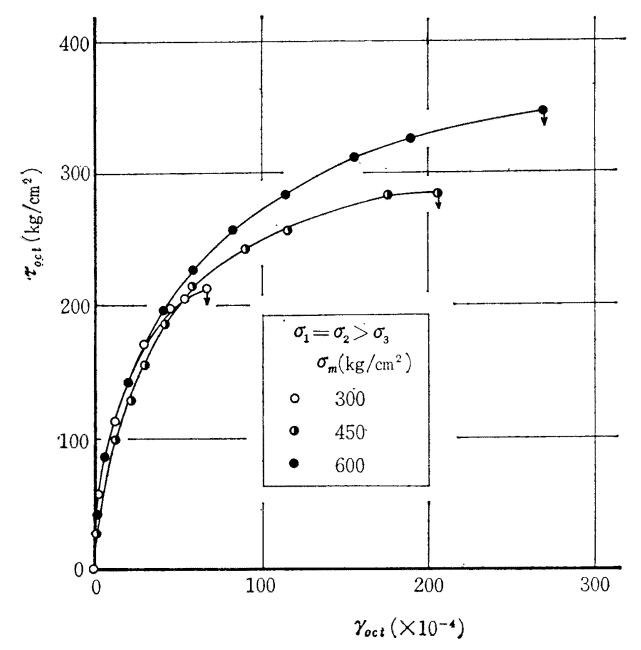

図一1 三軸圧縮応力下でのモルタルの応力ーひずみ曲線

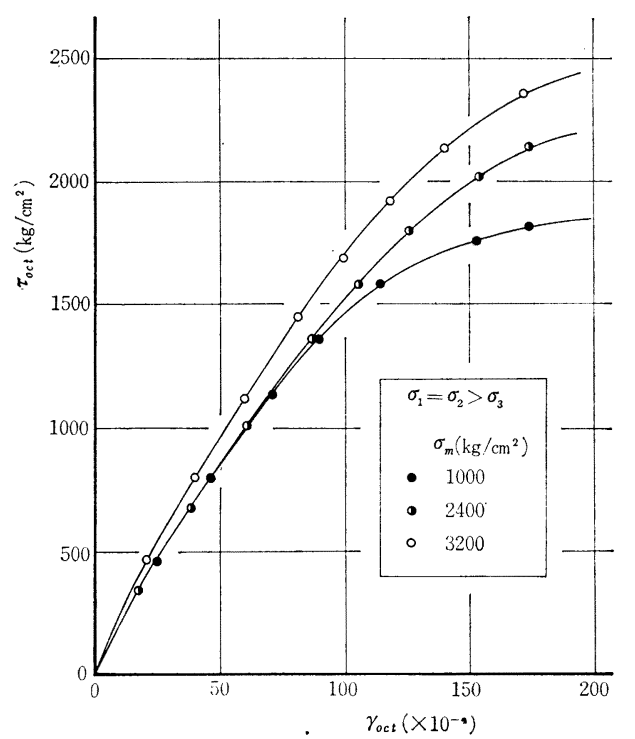

図-2 三軸圧縮応力下での片麻岩の応力ーひずみ曲線

関係沙非線形性を示し，roct の值が大きくなる。応力一 ひずみ関係が著しく非線形性を示しはじめる応力 $\sigma_{\text {oct }}$ のレベルやその後の破壞までのひずみ $\gamma_{\text {oct }}$ の伸びは当 然 $\sigma_{m}$ の值によって変化するが，このことは前論文でも 説明したように，破壞包絡線と応力円との関係からも考 えられることである。

このような応力ーひずみの非線形関係を有限要素解析 に導入する場合, その関係が数式化されていると便利で ある。図一1 ないし 3 のように得られた応力ーひずみ曲 線は級数表示で数式化できるが，前論文では bi-linear な関係（前論文中の図一8）および指数関数的関係（前 論文中の図一11) によって近似的に表示した。モルタル や岩石のようにぜい性な材料の場合でも，とくに材料が 密な場合には, 応力の低いレベルでは $\sigma_{m}$ に関倸なく同

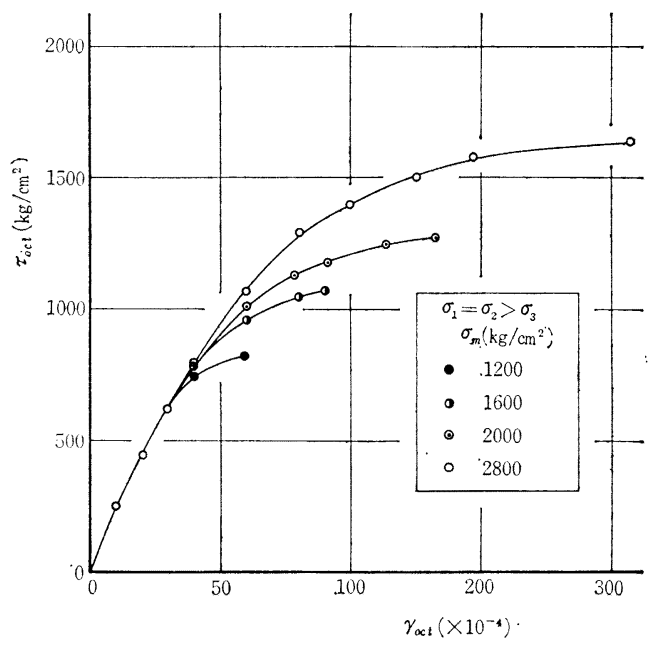

図-3 三載压縮応力下での大理石の応力ーひずみ曲線

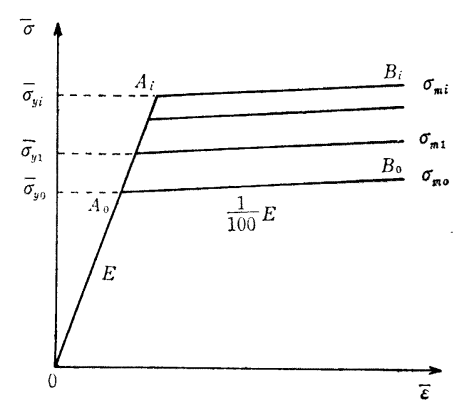

図一4 解析に用いられた bi-linear な応力-ひずみ関係

じ変形挙動を示し, 降伏領域以後ではひずみの増大が著 しくなるから， bi-linear な関係で近似する方が妥当で あるように思われる。この関数をあらためて図一4に示 す。なお，図一4では主応力差の半分 $\bar{\sigma}$ と主ひずみ差 $\bar{\varepsilon}$ の関倸を, 主応力和 (平均応力) $\sigma_{m}$ をパラメーターと して表示しているが，ここで取り扱っている軸対称問題 では, $r z$ 平面内に最大, 最小主応力があり, 切線方向 主応力 $\sigma_{\theta}$ が中間主応力になるので, $\sigma_{r}, \sigma_{z}, \tau_{r z}$ より主 応力 $\sigma_{1}, \sigma_{3}$ を求め, $\sigma_{\theta}=\sigma_{2}$ とし, 破壊に対する中間主 応力の影響を無視している。したがって $\bar{\sigma}=\left(\sigma_{1}-\sigma_{3}\right) / 2$, $\bar{\varepsilon}=\varepsilon_{1}-\varepsilon_{3}, \sigma_{m}=\left(\sigma_{1}+\sigma_{3}\right) / 2$ で表わされる。

応力ーひずみ関係のこのような近似的な取り扱いは, 前論文においても示したように, 荷重増加による塑性域 の拡がりや破壊強度に大きくは影響しないようである。 それは降伏条件が応力状態によって与えられるからであ るが, 荷重増加に伴う変形挙動や破壊時の供試体の最大 変形量等を正しく算定するには, 正確な応力ーひずみ関 係を計算侸導入することが当然必要である。

つぎに, 三軸圧縮試験により得られたモルタルの破壊 包絡線の例を示すと図一5のようである。この図からわ かるように, 破壊包絡線の形は主応力状態および荷重履 


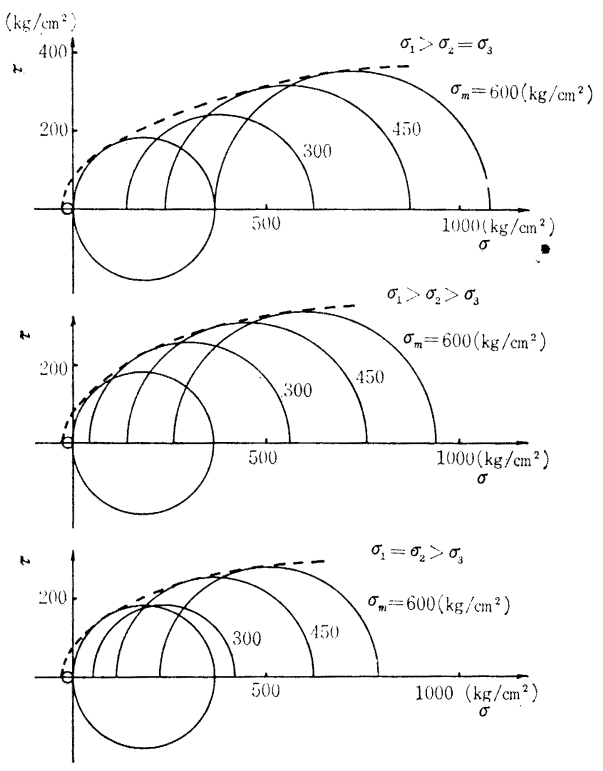

図一5 種々の三軸応力状態に対するモルタルの破壊包絡線

歴にいくらか影響されるようである。前論文ではこの包 絡線に対して Griffith 理論により修正された Mohr の 包絡線

$$
\tau^{2}=4 \sigma_{t}\left(\sigma_{t}-\sigma\right)
$$

を用いた。この降伏条件は材料の一軸引張強度 $\sigma_{t}$ によ って規定されるが, その後の検討の結果, 図一5 に示す 破壊包絡線はむしろ一軸引張強度 $\sigma_{t}$ とせん断強度 $\tau_{0}$ に よって規定される

$$
\tau^{2}=\tau_{0}^{2}\left(1-\sigma / \sigma_{t}\right)
$$

によって表わす方が適当であることが明らかになった。

円柱供試体の一軸圧縮試験時の各要素における忘力状 態はほとんど一軸的であり，破壊近くの要素におけるモ 一ルの応力円は $\tau$ 軸に近いところで降伏条件（破壊包絡 線）に近づくことが考えられるから，低い忘力レベルで の降伏条件がとくにこの場合の解析に影響をおよぼすも のと思われる。それで，ここでは図一6に示すような三 種の降伏条件を考え, 塑性域の発達過程と圧縮破壊強度 の比較を行なった。図中, 降伏条件 1 は $\tau^{2}=4 \sigma_{t}\left(\sigma_{t}-\sigma\right)$

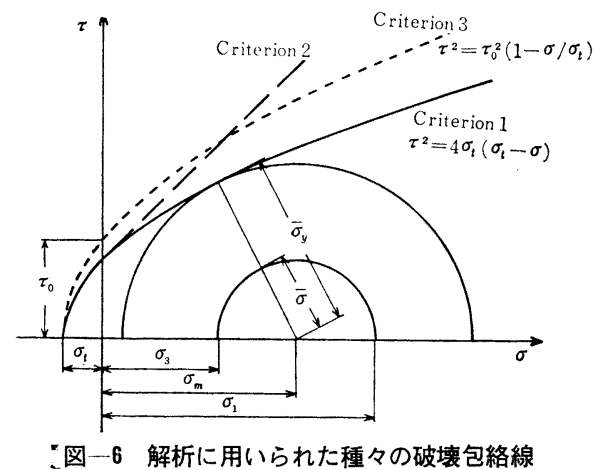

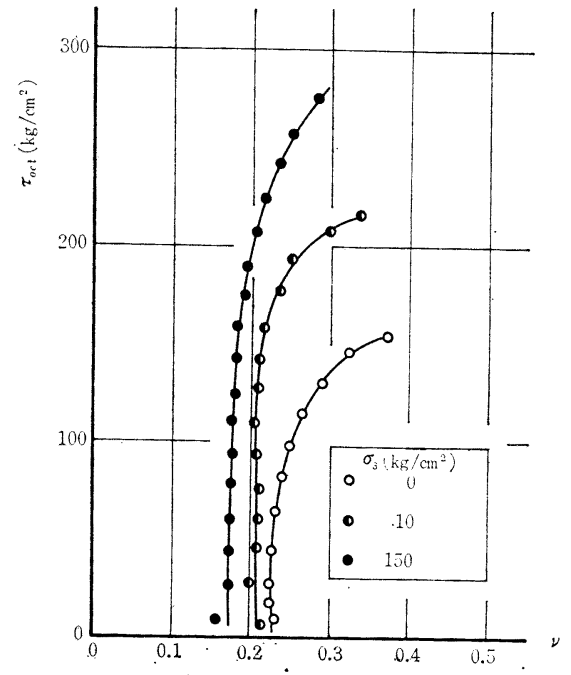

図一7 モルタルのポアンン比の変化

で与えられるものであり,降伏条件 2 は $\sigma<0$ では $\tau^{2}=$ $4 \sigma_{t}\left(\sigma_{t}-\sigma\right)$ で， $\sigma>0$ では $\sigma=0$ の点でさきの曲線に接 する直線で与えられるものである。また, 降伏条件 3 は $\tau^{2}=\tau_{0}\left(1-\sigma / \sigma_{t}\right)$ で与えられるものである。

解析はモルタル供試体を対象にして, 一軸引張強度を $\sigma_{t}=-30 \mathrm{~kg} / \mathrm{cm}^{2}$ とし, 降伏条件 3 では図一5 の実験值 より $\tau_{0}=70 \mathrm{~kg} / \mathrm{cm}^{2}$ と $75 \mathrm{~kg} / \mathrm{cm}^{2}$ の場合を考えた。なお 降伏条件 1 および 2 の場合は $\tau_{0}=60 \mathrm{~kg} / \mathrm{cm}^{2}$ の場合にあ たる。

解析に用いたモルタル材料のポアソン比は $\nu=0.2$ と し, 塑性状態になった領域の要素に対しては, 0.45 とし た。図一7 に示すモルタルに対する実験結果の例から明 らかなように, モルタルのポアソン比は材料が降伏する までにほぼ一定值であると考えてよいようである。

\section{3. 解析法について}

現在, 有限要素法を用いた弾塑性問題の解析には, 大 別して二つの方法がある。その一つはいままでよく用い られてきた incremental elasticity process ${ }^{3}$ であり, 他 の一つは最近話題になってきている initial stress process $^{4}$ ) である。O.C. Zienkiewicz らは後者の方法によ る解析の方が収束性のよいことを指摘しているが，ここ では前者の方法を用いた。この incremental elasticity process では, さらに荷重漸増法と反復法が考えられ, 各 荷重段階あるいは各計算段階における解析領域内各要素 の弾性性質をその前の段階における応力状態に対応させ て逐次変化させ計算を進めて行くものである。本研究で は,荷重漸増法と反復法による計算結果を比較している。

解析モデルとして, 直径 $10 \mathrm{~cm}$, 高さ $20 \mathrm{~cm}$ の円柱供 試体がその加圧面で半径方向変位を完全に拘束されなが 
ら，軸方向に等変位を与えられるように載荷される場合 を考える。漸増法による解析では，加圧面の任意のある 軸方向変位量に対して任意の要素の応力状態が降伏条件 を満足していないときには, それからの変位増分に対し ては，一定の弾性係数 $E$ およびポアソン比ン（図一4の 直線 $\overline{O A_{i}}$ に相当する）を用い，変位の增加につれて降 伏条件を満足した要素がでてくれば，その要素の変形係 数およびポアソン比を塑性域に対する値（図一4の直線 群 $\overline{A_{i} B_{i}}$ に相当する) に変化させて順次計算が進められ る。モルタルに対しては, 弾性状態にある要素に対して $E=2.1 \times 10^{5} \mathrm{~kg} / \mathrm{cm}^{2}, \nu=0.2$ とし, 降伏条件を満たし， 塑性状態になった領域の要素に対しては，その変形係数 を弾性係数 $E$ の $1 / 100$ 倍とし, ポアソン比を 0.45 とし て解析を進めた。

反復法による解析ではつぎのように計算が進められ た。まず与えられた全荷重（この場合には加圧面の朝方 向変位であるが）に対して，第一段階として初期弾性係 数とポアソン比を用いて線形弾性解析を行ない，その結 果得られる各要素の応力成分を用いて降伏条件をチェッ クする。たとえば，ある要素の主応力成分 $\left(\sigma_{1}, \sigma_{2}, \sigma_{3}\right)$ より， $\bar{\sigma}_{0}=\left(\sigma_{1}-\sigma_{3}\right) / 2$ と， $\sigma_{m 0}=\left(\sigma_{1}+\sigma_{3}\right) / 2$ のもとでの $\bar{\sigma}_{y}$ とを比較し， $\bar{\sigma}_{0}<\bar{\sigma}_{y}$ の場合にはその要素は弾性のまま でとどまる。一方， $\bar{\sigma}_{0}>\bar{\sigma}_{y}$ の場合にはその要素は塑性 状態となり，図一8 亿示すように, $\left(\varepsilon_{1}-\varepsilon_{3}\right)_{0}=\left(\varepsilon_{1}-\varepsilon_{3}\right)_{1}$ の仮定のもとで，そのときの $\sigma_{m 0}$ に応じた降伏応力状態 まで応力状態をもどし， $\bar{\sigma}_{0}$ が塑性時の応力状態を越えな いように変形係数の修正を行なう。この修正はすべての 要素に対して行なわれ，あらためて stiffness matrix が 作り直され, 全荷重に対して通带の線形弾性解析が行な われる。この繰り返し計算を解が収束するまで行なう。 図一8 には応力ーひずみ関係が $\bar{\sigma} \sim \bar{\varepsilon}$ で示されているか ら, 図の直線 $\overline{O A_{0}}$ や $\overline{O A_{1}}$ の傾斜は，それぞれせん断 弾性係数 (あるい変形係数) $G_{0}, G_{1}$ などを与える。

反復計算のある段階 $i$ において $G_{i}$ に対応した $E_{i}$ お よび $\nu_{i}$ を用いて計算された応力成分 $\left(\sigma_{1}, \sigma_{3}\right)_{i}$ より,つ ぎの計算段階に用いられる $E_{i+1}$ は，図一8 に示寸関倸 より，一般に次式で与えられる。

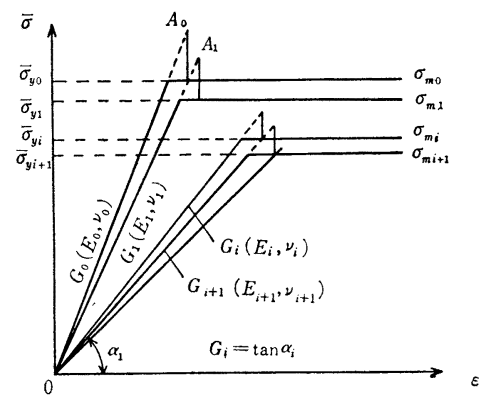

図一8 反復法における変形係数の修正

$$
E_{i+1}=\frac{\left(1+\nu_{i+1}\right)}{\left(1+\nu_{i}\right)} \cdot \frac{\tilde{\sigma}_{y}}{\bar{\sigma}_{i}} \cdot E_{i}
$$

ここで, ポアソン比としては弾性域で 0.2 , 塑性域で 0.45 を用いている。

\section{4. 塑性域の発達過程および破壊強度}

漸増法によって解析された結果から，降伏条件の相違 による塑性域の 発達過程 および破壊強度を比較してみ る。降伏条件 1 および 2 では $\sigma_{t}=-30 \mathrm{~kg} / \mathrm{cm}^{2}\left(\tau_{0}=60\right.$ $\mathrm{kg} / \mathrm{cm}^{2}$ に相当する) を与え, 降伏条件 3 では $\sigma_{t}=-30$ $\mathrm{kg} / \mathrm{cm}^{2}$ と $\tau_{0}=70 \mathrm{~kg} / \mathrm{cm}^{2}$ および $75 \mathrm{~kg} / \mathrm{cm}^{2}$ を与えてい る。直径 $10 \mathrm{~cm}$, 高さ $20 \mathrm{~cm}$ の円柱供試体が初期弾性係 数 $E_{0}=2.1 \times 10^{5} \mathrm{~cm}^{2}$, ポアソン比 $\nu=0.2$ をむつのと し，その加圧面での半径方向変位を完全何拘束した状態 で軸方向変位を与えるように加圧された。この供試体の 破壊強度としては，供試体を横切って塑性域が抎がった 時点での軸方向変位に相応した全荷重より求められた平 均軸方向応力がとられた。

それぞれの降伏条件に対する塑性域の発達の様子を図 に示すと，図一9，10，11 (a)，(b) のようである。これ らの図は加えられた加圧面での軸方向変位量の大きさで 示され，同時にその変位量に相当した平均軸方向応力值 (平均荷重強度) が示されている。これらの図より，塑 性域の発達する様子は降伏条件のいかんにかかわらずほ ぼ同じようであり，同じような応力ーひずみ関倸を有す るぜい性材料円柱供試体の一軸圧縮試験時の破壊機構は ほぼ類似しているものと思われる。しかし，図から明ら かなように，供試体の破壊時の平均荷重強度の大きさお よび加圧面の変位量は, 降伏条件とくに $\tau_{0}$ の值によっ
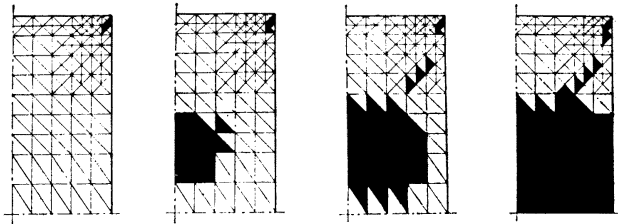

$u_{z}^{u}=0.0110 \mathrm{~cm} \quad u_{z}^{\prime}{ }^{u}=0.0111 \mathrm{~cm} \quad u_{z}^{u}=0.0112 \mathrm{~cm} \quad u_{z}^{u}=0.0114 \mathrm{~cm}$ $p=233 \mathrm{~kg} / \mathrm{cm}^{2} \quad p=235 \mathrm{~kg} / \mathrm{cm}^{2} \quad p=237 \mathrm{~kg} / \mathrm{cm}^{2} \quad p=238 \mathrm{~kg} / \mathrm{cm}^{2}$

図一9降伏条件 1 のもとでの荷重漸増法による 塑性域の発達過程
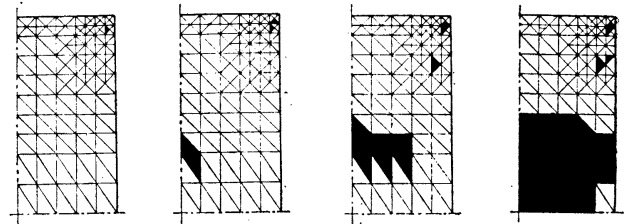

$u_{z}^{u}=0.0131 \mathrm{~cm} \quad u_{z}^{u}=0.0123 \mathrm{~cm} \quad u_{z}^{u}=0.0133 \mathrm{~cm} \quad u_{z}^{u}=0.0134 \mathrm{~cm}$ $p=277 \mathrm{~kg} / \mathrm{cm}^{2} \quad p=279 \mathrm{~kg} / \mathrm{cm}^{2} \quad p=281 \mathrm{~kg} / \mathrm{cm}^{2} \quad p=283 \mathrm{~kg} / \mathrm{cm}^{2}$

図一10降伏条件 2 のもとでの荷重漸增法による 塑性域の発達過程 

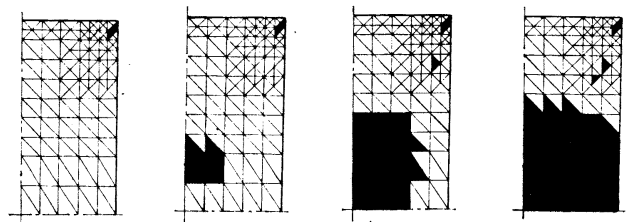

$u_{z}{ }^{u}=0.0138 \mathrm{~cm} \quad u_{z}{ }^{u}=0.0140 \mathrm{~cm} \quad u_{z}^{u}=0.0141 \mathrm{~cm} \quad u_{z}^{u}=0.0142 \mathrm{~cm}$ $p=292 \mathrm{~kg} / \mathrm{cm}^{2} \quad p=296 \mathrm{~kg} / \mathrm{cm}^{2} \quad p=298 \mathrm{~kg} / \mathrm{cm}^{2} \quad p=300 \mathrm{~kg} / \mathrm{cm}^{2}$

(a) $\sigma_{\iota}=-30 \mathrm{~kg} / \mathrm{cm}^{2}, \tau_{0}=70 \mathrm{~kg} / \mathrm{cm}^{2}$
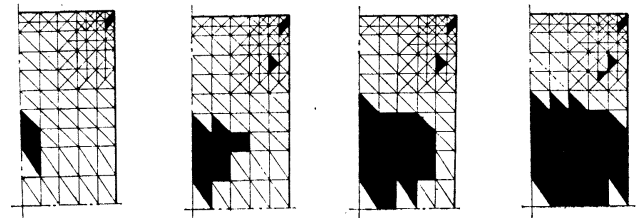

$u_{z}{ }^{u}=0.0155 \mathrm{~cm} \quad u_{z}{ }^{u}=0.0156 \mathrm{~cm} \quad u_{z}{ }^{u}=0.0157 \mathrm{~cm} \quad u_{z}{ }^{u}=0.0158 \mathrm{~cm}$ $p=328 \mathrm{~kg} / \mathrm{cm}^{2} \quad p=330 \mathrm{~kg} / \mathrm{cm}^{2} \quad p=331 \mathrm{~kg} / \mathrm{cm}^{2} \quad p=333 \mathrm{~kg} / \mathrm{cm}^{2}$

(b) $\sigma_{t}=-30 \mathrm{~kg} / \mathrm{cm}^{2}, \tau_{0}=75 \mathrm{~kg} / \mathrm{cm}^{2}$

図一11降伏条件 3 のもとでの荷重漸增法による 塑性域の発達過程

\begin{tabular}{|c|c|c|c|c|c|}
\hline \multicolumn{6}{|c|}{ 表一1 } \\
\hline \multirow{2}{*}{\multicolumn{2}{|c|}{ 降 伏 条 件 }} & \multirow{3}{*}{$\frac{\begin{array}{c}\sigma_{t} \\
\left(\mathrm{~kg} / \mathrm{cm}^{2}\right)\end{array}}{30}$} & \multirow{3}{*}{$\begin{array}{c}\begin{array}{c}\tau_{0} \\
\left(\mathrm{~kg} / \mathrm{cm}^{2}\right)\end{array} \\
(60)\end{array}$} & \multirow{2}{*}{ 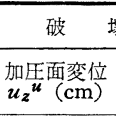 } & \multirow{2}{*}{ 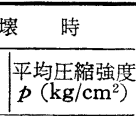 } \\
\hline & & & & & \\
\hline 1 & $\tau^{2}=4 \sigma_{t}\left(\sigma_{t}-\sigma\right)$ & & & 0.0114 & 234 \\
\hline 2 & $\begin{array}{l}\sigma<0 \sigma \succeq t \\
\tau^{2}=4 \sigma_{t}\left(\sigma_{t}-\sigma\right) \\
\sigma>0 \sigma \zeta \\
\tau=\sigma-2 \sigma_{t}\end{array}$ & 30 & $(60)$ & 0.0134 & 283 \\
\hline \multirow{2}{*}{3} & \multirow{2}{*}{$\tau^{2}=\tau_{0}^{2}\left(1-\sigma / \sigma_{t}\right)$} & \multirow{2}{*}{30} & 70 & 0.0142 & 300 \\
\hline & & & 75 & 0.0158 & 333 \\
\hline
\end{tabular}

てかなり変化することがわかる。これらの值をまとめて 表示すると表一1 のようである。

加圧面の半径方向変位を拘束した場合の破壊時の平均 応力は, 降伏条件 3 で $\tau_{0}=75 \mathrm{~kg} / \mathrm{cm}^{2}$ を用いたときに は, $\sigma_{c}=333 \mathrm{~kg} / \mathrm{cm}^{2}$ であるのに対して, モルタル供試体 での実験值は $\sigma_{c}=335.6 \mathrm{~kg} / \mathrm{cm}^{2}$ で, かなりよい一致を 示している。破壊時の軸方向全変形量を比較すると, 解 析值では $\delta=2 u_{z}{ }^{u}=0.316 \mathrm{~mm}$ に対して, 実験值は $\delta=$ $0.6 \sim 0.8 \mathrm{~mm}$ とかなり大きい值を示しているが, 実験で の值は供試体が分離した後の值まで入っているので，当 然大きな值となり，正確には比較することは不可能であ る。さらに実験で得た供試体の破壞形状（前論文写真一 1 参照）と，解析によって得た塑性域の拡がる過程から 考察すると, 円柱供試体の破壊は，その中央部分から発 達した塑性域が供試体を横切って変形能を増すことに原 因して，加圧面下の剛性の高いくさび形の領域（前論文 中の 図一13 からも明らかなように，供試体中央部に塑 性域が発達した時点においても加圧面近傍では弾性係数 の低下が㧍こらない領域ができている）が中央部の塑性 域化押し込まれるような状態で抗こっているように思わ
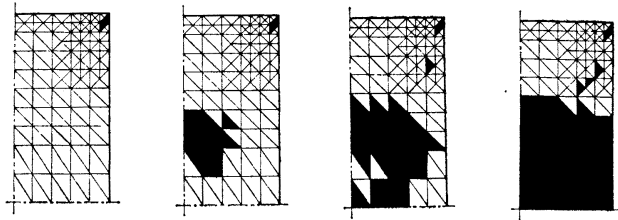

$u_{z}{ }^{u}=0.0110 \mathrm{~cm} u_{z}{ }^{u}=0.0111 \mathrm{~cm} \quad u_{z}^{u}=0.0112 \mathrm{~cm} \quad u_{z}^{u}=0.0114 \mathrm{~cm}$ $p=233 \mathrm{~kg} / \mathrm{cm}^{2} \quad p=235 \mathrm{~kg} / \mathrm{cm}^{2} \quad p=237 \mathrm{~kg} / \mathrm{cm}^{2} \quad p=238 \mathrm{~kg} / \mathrm{cm}^{2}$

図一12 降伏条伏 1 のもとでの反復法による 塑性域の発達過程

れる。

つぎに，漸増法と反復法による結果を比較してみる。 降伏条件として条件 1 を用い，応力ーひずみ関係を図一 4 に示すものと同じものを用いて解析を行なった。ただ し, 反復法の場合には塑性域での変形係数は 0 亿なる。 すなわち, 図一4 の忘力ーひずみ関倸で, 塑性域では $\bar{\varepsilon}$ 軸 に平行な直線を用いたことになる。漸増法の場合には図 一9に解析結果が示されているが, 反復法に対するもの を示すと 図一12 のよらである。いくつかの加圧面の軸 方向変位量に対する塑性域の拡がりは完全には一致して いないが，ほぼ等しく，その発達過程は全く同一である ことがわかる。また, 加圧面の変位量に対応した平均軸 方向応力の大きさや破壊荷重強度はまったく一致してお り, この場合の問題は, 漸増法で解いても反復法で解い ても同一の結果を与えていると考えてよいだろう。

\section{5.あとがき}

解析結果と実験值の比較より, 有限要素法をモルタル や岩石のようなぜい性材料の破壊形状の解析に適用する ことが有効であるように思われる。解析結果は, 材料の 降伏条件の違いにかかわらず，ほぼ同一の塑性域の発達 （破壞機構）を示し，また解析に導入した降伏条件が適切 であれば, 破壊強度も実験值とほとんど一致することが わかった。しかし，ここで取りあげた問題のようにぜい 性体の破壞に対する解析では, 引張り応力状態あるいは 一軸圧縮応力に近い状態で降伏条件を満たす場合がほと んどであるから, 引張り応力領域ならびに圧縮応力の低 レレベルでの材料の降伏条件, 寸なわち, 破壊包絡線を はっきり把握して, 有限要素解析に導入しなければなら ない。この点から考えて,モルタルの降伏条件としては, その引張強度とせん断強度とによって規定される式 (4) の条件の方が Griffith-Mohr の降伏条件よりも妥当であ る。

本論文で示した解析では要素内で応力あるいはひずみ が一定となり, 各要素間でのそれらの不連続性が解析結 果に影響を与えることは当然考えられる。したがって， 各計算段階における塑性域もスムーズな形とならない。 
この点については要素の細分化によって解決されるが， 著者らはさらに要素内で応力が線形変化する 6 節点三角 形要素を使用して弾塑性解析を進めている。

なお, 有限要素法を, 逐次進行する現象としての破壊 状態の解析に適用するためには, 今後, 不連続性の発生 を合理的に表現するモデルを考えた解析を進め, さらに 検討が加えられるべきであると思う。

終わりに, 本研究を行ならにあたり, モルタルおよび 岩石の三軸圧縮試験に協力いただいた当教室秋本昌胤助 手および中日本建設コンサルタント 富田和政君に感謝 の意を表する次第である。

\section{参考 文 献}

1）梶田建夫・秋本昌㸝・川本朓万：円柱状せい性 材料供試 体の一軸圧縮試験における 加俚面拘束が変形状態 および 圧縮強度におよぼす影響について, 土木学会論文報告集, 166 , pp. $27 \sim 38$ (1969).

2）富田和政・秋本昌胤・川本朓万：三軸圧縮下に おけるモ ルタルの変形特性, 土木学会論文報告集, 175, pp. 75 83, (1970-3)

3) O.C. Zienkiewicz and Y.K. Cheung: The Finite Element Metheod in Structural and Continuum Mechanics, McGraw Hill, 1967, pp. 192 201.

4) O.C. Zienkiewicz, et al : Elasto-plastic Solutions on Engineering Problems 'Initial Stress' Finite Element Approach, International Journal for Numerical Methods in Engineering, 1 (1969), pp. 75 100.

(1969.9.20 - 受付) 